\title{
Propolis or cashew and castor oils effects on composition of Longissimus muscle of crossbred bulls finished in feedlot
}

\author{
Maribel Velandia Valero ${ }^{1}$, Juliana Akamine Torrecilhas ${ }^{1}$, Fernando Zawadzki ${ }^{1}$, \\ Elton Guntendorfer Bonafé2, Grasiele Scaramal Madrona ${ }^{3}$, Rodolpho Martin do Prado', \\ Rodrigo Augusto Cortêz Passetti ${ }^{1}$, Dayane Cristina Rivaroli' ${ }^{1}$ Jesuí Vergílio Visentainer ${ }^{2}$, \\ and Ivanor Nunes do Prado ${ }^{*}$
}

The natural additive products (propolis or essential oils), in replacing antibiotics, could be used as an alternative for feed strategies to improve animal production. This work was performed to evaluate the effect of natural additives as propolis or essential oils on meat quality of crossbred (Aberdeen Angus vs. Nellore) bulls. Thirty bulls were kept in feedlot (individual pen) for $55 \mathrm{~d}$ and randomly assigned to one of three diets $(n=10)$ : control (CON), propolis (PRO), or essential oils (OIL). CON diet consists of corn silage (45\% DM) and concentrate (cracked corn, soybean meal, glycerin, limestone, and mineral salt, 55\% DM). The PRO group received same CON diet plus $3 \mathrm{~g}$ animal ${ }^{-1} \mathrm{~d}^{-1}$ of propolis premix added to the concentrate. The OIL group received same CON diet and $3 \mathrm{~g}_{\text {animal }}^{-1} \mathrm{~d}^{-1}$ of a premix (cashew Anacardium occidentale L. and castor Ricinus communis L. oils) added to the concentrate. Fat thickness (5.0 mm), pH (5.9), Longissimus muscle area $58.0 \mathrm{~cm}^{2}$, marbling, texture, color $\left(\mathrm{L}^{*}=36.6, \mathrm{a}^{*}=17.3\right.$, and $\left.\mathrm{b}^{*}=5.9\right)$, lipid oxidation $\left(0.08\right.$ malonaldehyde $\mathrm{kg}^{-1}$ meat $)$, and WarnerBratzler shear force $(3.3 \mathrm{~kg})$ were unaffected by the diet. PRO and OIL diets had no effect neither on moisture $(73.7 \%)$, ashes $(1.1 \%)$, protein $(23.8 \%)$, and lipids (1.7\%), fatty acid composition or polyunsaturated/saturated fatty acid (PUFA/ SFA, 0.13), and $n-6 / n-3$ ratio (6.9) on Longissimus muscle. Addition of natural additives as propolis extract or cashew and castor oils in the diet of bulls when they are finished in a feedlot did not change meat qualities.

Key words: Additives, cattle, essential oils, fatty acid, glycerin, PUFA.

\section{INTRODUCTION}

For intensive finishing systems in beef cattle requiring high energy, it is necessary to increase the use of grains and cereals (Ito et al., 2010). When ruminants are fed forage, rumen $\mathrm{pH}$ is generally near neutral (i.e. 6.8); however, when finishing rations containing large amounts of cereal grain are fed, rumen $\mathrm{pH}$ can drop drastically. Therefore, ionophores additives were used in cattle diets to modulate rumen fermentation (Valero et al., 2011; Zawadzki et al., 2011b). The use of ionophores is well-documented in ruminant nutrition; they improve growth, feed intake and efficiency (Russell and Houlihan, 2003). However, the use of ionophores can cause the transmission and proliferation

\footnotetext{
${ }^{1}$ Universidade Estadual de Maringá, Departamento de Zootecnia, Av. Colombo, 5790, Maringá, Paraná, Brasil.

*Corresponding author (inprado@uem.br).

${ }^{2}$ Universidade Estadual de Maringá, Departamento de Química, Av. Colombo, 5790, Maringá, Paraná, Brasil.

${ }^{3}$ Universidade Estadual de Maringá, Departamento de Ciência de Alimentos, Av. Colombo, 5790, Maringá, Paraná, Brasil.

Received: 30 January 2014.

Accepted: 18 July 2014.
}

doi: $10.4067 /$ S0718-58392014000400011 of resistant bacteria via food chain (Schäberle and Hack, 2014).

New natural additive products have been studied as a partial alternative for feed strategies to improve animal production including propolis or essential oils (Benchaar et al., 2008; Valero et al., 2011; Zawadzki et al., 2011b). Such products have several advantages over commonly used ionophores, since they are residue free and are generally regarded as safe in the food industry. These compounds have received increased attention in the previous decade as possible growth promoters for animals (Benchaar et al., 2008; Patra, 2011).

Propolis is a potential growth promoter, with numerous pharmacological properties (Righi et al., 2011). When propolis is administered to animals its action is similar to ionophores, as observed through in vivo and in vitro experiments (Prado et al., 2010a). The potent bacteriostatic and bactericidal effects of propolis are the result of the combined actions of several such components. Havsteen (2002) suggests that the specific propolis ingredients inhibit protein synthesis and bacterial growth by preventing cell division, resulting in the formation pseudo-multicellular bacterial forms. Some active substances composing propolis may disorganize the cytoplasmic membrane and cell wall, with the effects 
of a partial bacteriolysis. Propolis has positive results in studies involving animal nutrition, such as increased in vitro digestibility and better feed efficiency (Zawadzki et al., 2011b).

Essential oils are aromatic compounds obtained from plant parts (flowers, buds, seeds, leaves, twigs, bark, herbs, wood, fruits, and roots), being complex mixtures of secondary plant metabolites consisting of lowboiling-phenylpropenes and terpenes. Essential oils are particularly associated with plant characteristic essences and fragrances (Greathead, 2003). In addition to their traditional uses, valuable effects have been reported by experimental studies during the previous three decades, including positive influences on lipid metabolism, ability to stimulate digestion, antimicrobial, antioxidant and antiinflammatory properties (Benchaar et al., 2008; Patra, 2011). Essential oils and plant extracts are associated with the current concern about the future of global agriculture and consumers' preferences for natural products.

The objective of this study was assess the effect of natural dietary additives as propolis and essential oils as cashew and castor oils on $\mathrm{pH}$, fat thickness, Longissimus area, marbling, texture, color, lipid oxidation, shear force and chemical composition of meat of crossbred bulls finished in a feedlot system.

\section{MATERIALS AND METHODS}

\section{Local, animals, housing, and diets}

This experiment was conducted at Rosa Pedro Sector of Experimental Station at Farm Iguatemi (23⒉ $5^{\prime} \mathrm{S}, 51^{\circ} 57^{\prime}$ W; 550 m a.s.1.), Maringá, Paraná, Brazil. Thirty crossbred bulls (1/2 Aberdeen Angus vs. 1/2 Nellore), 20-mo-old and weighed $387 \pm 6.3 \mathrm{~kg} \mathrm{LW}$, were used in a completely randomized design. Bulls were weighed and randomly distributed into three diet groups $(n=10)$ : control $(\mathrm{CON})$, propolis (PRO) addition or essential oils addition. Bulls were housed in individual pens with $10 \mathrm{~m}^{2}$ and concrete floors. The diet compositions and proportion are shown in Tables 1 and 2, respectively. Before experimental period, bulls had a $14 \mathrm{~d}$ adaptation period. The bulls were fed twice a day at 08:00 and 16:00 h. Diets were weighed daily for $5 \%$ refusals. The intake of concentrate and corn (Zea mays L.) silage were recorded daily until day 55 of the experimental period. Both diet formulation and quantity supplied were designed to provide a weight gain of $1.5 \mathrm{~kg} \mathrm{~d}^{-1}$ (NRC, 2000). The glycerin was used as an energetic ingredient in the diet; therefore, the glycerin level was counterbalanced mainly by a decrease in corn grain content. The glycerin was produced in a soy-diesel facility (BIOPAR, Rolândia, Paraná, Brazil). PRO group was supplemented with $3 \mathrm{~g}_{\text {animal }}^{-1} \mathrm{~d}^{-1}$ as a premix added in the concentrate according (Prado et al., 2010b). The propolis product contained $0.054 \mathrm{mg} \mathrm{g}^{-1}$ total flavonoids in chrysin. For the OIL group, was added $3 \mathrm{~g}$ animal $^{-1} \mathrm{~d}^{-1}$ in the commercial mix (Oligo Basics Agroindustrial Ltda., Cascavel, Paraná, Brasil). Ricinoleic acid was obtained from castor oil (extracted from castor Ricinus communis L. seed) and anacardic, cardanol, and cardol acids were obtained from cashew nut shell liquid (obtained from the processing of cashew nuts Anacardium occidentale L.); both were produced in northern Brazil.

Bulls were slaughtered at a commercial slaughterhouse $30 \mathrm{~km}$ from the experimental farm, according to Brazilian industrial practices, when bulls reached a final $470 \pm 8.0$ $\mathrm{kg} \mathrm{BW}$ and 22-mo old.

\section{Sampling and meat quality}

After slaughter, carcasses were labeled and a cut was carried out following the vertebral column, yielding two similar halves. These carcasses were chilled for $24 \mathrm{~h}$ at $4{ }^{\circ} \mathrm{C}$. After chilling, the right side carcasses were used to measurements and sampling of Longissimus dorsi muscle $(\mathrm{LM})$ excised between $10^{\text {th }}$ and $13^{\text {th }}$ ribs. After

Table 1. Chemical composition of ingredients of diets.

\begin{tabular}{|c|c|c|c|c|c|c|c|c|c|c|}
\hline Parameters & $\begin{array}{l}\text { Corn } \\
\text { silage }\end{array}$ & $\begin{array}{l}\text { Corn } \\
\text { grain }\end{array}$ & $\begin{array}{c}\text { Soybean } \\
\text { meal }\end{array}$ & Glycerin & Urea & $\begin{array}{c}\text { Mineral } \\
\text { salt }^{1}\end{array}$ & Limestone & Propolis & $\begin{array}{l}\text { Essential } \\
\text { oils }\end{array}$ & Diet \\
\hline & & & & & $-\mathrm{g} \mathrm{kg}^{-1}$ & & & & & - \\
\hline Dry matter & 266 & 900 & 896 & 942 & 990 & 990 & 990 & 146 & 976 & 434 \\
\hline Organic matter & 964 & 987 & 942 & 10.0 & -- & -- & -- & -- & 559 & 807 \\
\hline Crude protein & 72.7 & 93.4 & 489 & 1.00 & 262 & -- & -- & -- & -- & 115 \\
\hline Ash & 35.4 & 12.5 & 58.3 & 47.6 & -- & 990 & 950 & -- & 440 & 40.1 \\
\hline Total nutrients digestible & 620 & 900 & 820 & 807 & -- & -- & -- & -- & & 73.8 \\
\hline Ether extract & 18.2 & 33.5 & 30.0 & 60.0 & -- & -- & -- & -- & 150 & 29.8 \\
\hline Neutral detergent fiber & 524 & 154 & 107 & -- & -- & -- & -- & -- & -- & 293 \\
\hline Acid detergent fiber & 316 & 49.3 & 103 & -- & -- & -- & -- & -- & -- & 166 \\
\hline Total carbohydrates & 874 & 861 & 423 & -- & -- & -- & -- & -- & -- & 689 \\
\hline Non fibrous carbohydrates & 350 & 706 & 316 & -- & & -- & -- & -- & -- & 396 \\
\hline \multicolumn{11}{|l|}{ Main fatty acids } \\
\hline $14: 0$ & 0.02 & 0.23 & 0.03 & 3.48 & -- & -- & -- & -- & -- & 0.60 \\
\hline $16: 0$ & 18.1 & 43.9 & 39.3 & 114.6 & -- & -- & -- & -- & -- & 42.7 \\
\hline 18:0 & 6.32 & 7.87 & 10.3 & 38.7 & -- & -- & -- & -- & -- & 12.2 \\
\hline $18: 1 n-9$ & 32.4 & 114 & 39.3 & 173 & -- & -- & -- & -- & -- & 80.0 \\
\hline $18: 1 n-7$ & 1.42 & 2.14 & 3.78 & 9.72 & -- & -- & -- & -- & -- & 3.10 \\
\hline $18: 2 n-6$ cis & 71.2 & 164 & 164 & 241 & -- & -- & -- & -- & -- & 133 \\
\hline $18: 3 n-3$ & 2.48 & 3.62 & 16.4 & 15.7 & -- & -- & -- & -- & -- & 5.9 \\
\hline
\end{tabular}

${ }^{1}$ Guarantee levels (per kg): 175 g Ca; 100 g P; 114 g Na; 15 g Se; 15 g Mg; 6.00 mg Zn; 1.25 mg Mn; 1.88 mg Cu; 180 mg I; 125 mg Co; 1.00 mg F (maximum). 
Table 2. Diets composition.

\begin{tabular}{lccc}
\hline & \multicolumn{3}{c}{ Diets } \\
\cline { 2 - 4 } Ingredients & $\mathrm{CON}$ & PRO & OIL \\
\cline { 2 - 4 } & \multicolumn{4}{c}{$\mathrm{g} \mathrm{kg}^{-1} \mathrm{DM}$} & \\
Corn silage & 454 & 454 & 454 \\
Corn grain & 305 & 305 & 305 \\
Soybean meal & 70.8 & 70.8 & 70.8 \\
Glycerin & 154 & 154 & 154 \\
Urea & 7.26 & 7.26 & 7.26 \\
Mineral salt & 4.47 & 4.47 & 4.47 \\
Limestone & 4.46 & 4.42 & 4.42 \\
Propolis & - & 0.55 & - \\
Essential oils & - & - & 0.55 \\
\hline
\end{tabular}

CON: Control diet, PRO: diet with propolis inclusion, OIL: diet with essential oils inclusion.

measurements of $\mathrm{pH}_{24 \mathrm{~h}}$, fat thickness, $\mathrm{LM}$ area, marbling, texture, and color, steaks of LM from $10^{\text {th }}, 11^{\text {th }}$, and $12^{\text {th }}$ ribs were placed in unsealed plastic bags and frozen immediately for other meat analyses.

The $\mathrm{pH}_{24 \mathrm{~h}}$ was measured using a $\mathrm{pH}$ Meter Text Model (Tradelab, Contagem, Minas Gerais, Brazil) and a penetration ph-electrode at the point of the $10^{\text {th }}$ rib on LM. Fat thickness, LM area, marbling, texture, and color were determined on surface of $12^{\text {th }}$ rib after a crosssectional cut performed between $12^{\text {th }}$ and $13^{\text {th }}$ ribs, $24 \mathrm{~h}$ post slaughter. Fat thickness was measured using a caliper to average three points over LM. Longissimus muscle area was measured using a compensating planimeter that measures the area of irregular shaped objects. Marbling was measured using scoring system (18 to 16: abundant, 15 to 13: moderate, 12 to 10: mean, 9 to 7 : small, 6 to 4 : light, 3 to 1: traces). Texture was determined by fascicle size (muscular "grain" size) and evaluated subjectively on a point scale (very fine: 5 , fine: 4 , slightly: 3 , coarse: 2 , very coarse: 1 ). The meat color in the CIELAB space was assessed using a Minolta CR-400 spectrophotometer (Illuminant D65, observer angle $10^{\circ}$, Konica Minolta Holdings, Osaka, Japan) at $30 \mathrm{~min}$ after blooming. Color coordinates expressed as $\mathrm{L}^{*}, \mathrm{a}^{*}$, and $\mathrm{b}^{*}$ were recorded, where $\mathrm{L}^{*}$ is the lightness of color whose values range from 0 for black to 100 for white, $\mathrm{a}^{*}$ is red/green value which range from $+\mathrm{a}^{*}$ for red to $-\mathrm{a}^{*}$ for green, and $\mathrm{b}^{*}$ is yellow/ blue value which range from $+b^{*}$ for yellow to $-b^{*}$ for blue. The chroma $\left(\mathrm{C}^{*}\right)$ and hue angle $\left(\mathrm{H}^{*}\right)$ indexes were calculated as $\mathrm{C}^{*}=\left(\mathrm{a}^{* 2}+\mathrm{b}^{* 2}\right)^{0.5}$ and $\mathrm{H}^{*}=\tan ^{-1}\left(\mathrm{~b}^{*} / \mathrm{a}^{*}\right)^{*}[360 \%$ $(2 * 3.14)]$ expressed in degrees.

Samples analyzed for thiobarbituric acid reactive substances (TBARS) were obtained of $10^{\text {th }} \mathrm{LM}$ rib after 12-mo freezing. Ten grams of meat were homogenized with $20 \mathrm{~mL}$ of $10 \%(\mathrm{w} / \mathrm{v})$ trichloroacetic acid using a homogenizer Ultra-Turrax (90 s, 20000 rpm; Fisher Scientific, Loughborough, UK). The homogenate was centrifuged and the supernatant decanted through a paper filter (Whatman nr 311643, Schleicher \& Schuell, Dassel, Germany). Two milliliters of filtrate were mixed with $2 \mathrm{~mL}$ TBA reagent (300 $\mathrm{mg}$ 2-thiobarbituric acid $100 \mathrm{~mL}^{-1} \mathrm{H}_{2} \mathrm{O}$ ). The mixture was heated in a water bath for $20 \mathrm{~min}$ to $97{ }^{\circ} \mathrm{C}$. After the mixture had cooled to ambient temperature, the extinction was measured at 532 $\mathrm{nm}$. The TBARS values are expressed as milligrams of malonaldehyde (MDA) per kilogram of meat.

Warner-Bratzler shear force (WBSF) was performed on LM from $11^{\text {th }}$ rib after defrosting. The muscle samples were separated into individual standardized $3.5 \mathrm{~cm}$ thick slices, placed in an electric oven, and cooked at a defined internal temperature $\left(72{ }^{\circ} \mathrm{C}\right)$. When the endpoint temperature was reached, samples were removed from the electric oven and maintained at room condition until they equilibrated. The WBSF mechanical properties of the meats were obtained using a texture analyzer (Stable Micro Systems TAXT Plus; Texture Technologies Corp., Surrey, UK) with a $5.0 \mathrm{~kg}$ load cell.

The chemical composition was determined with specific portion of LM from $12^{\text {th }}$ rib after defrosting. Samples were ground, homogenized, and analyzed in triplicate to determined moisture, protein, fat, and ash contents according to standardized protocols (ISO-R-1442, ISO-R-937, ISO-R-1443, and ISO-R-1998), respectively (AOAC, 1998).

For the fatty acids analyses, intramuscular fat was extracted with specific portion of the LM at the $12^{\text {th }}$ rib level with a chloroform/methanol mixture (Bligh and Dyer, 1959). Fatty acid methyl esters (FAMEs) were prepared using methylation. To quantify the fatty acid composition of meat and diets, the methyl ester preparation included $\mathrm{KOH}$ in methanol with methyl heneicosanoate (21:0), as an internal standard. Fatty acid methyl esters were analyzed through a gas chromatograph (Varian Medical Systems, Palo Alto, California, USA) equipped with a flame ionization detector and CP-7420 Select Fame fused silica capillary column $(100 \mathrm{~m}, 0.25 \mathrm{~mm}$ id, and $0.39 \mu \mathrm{m}$, Varian, USA). The column temperature was programmed at $165^{\circ} \mathrm{C}$ for $18 \mathrm{~min}, 180^{\circ} \mathrm{C}\left(30^{\circ} \mathrm{C} \mathrm{min}^{-1}\right)$ for $22 \mathrm{~min}$, and $240{ }^{\circ} \mathrm{C}\left(15^{\circ} \mathrm{C} \mathrm{min}-1\right)$ for $30 \mathrm{~min}$ with a 45 -psi pressure. The injector and detector were both maintained at 220 and $245{ }^{\circ} \mathrm{C}$, respectively. Gas fluxes (White Martins Gases Industriais, Praxair, Rio de Janeiro, Brazil) comprised 1.4

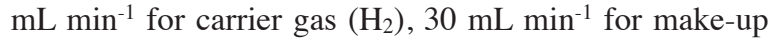
gas $\left(\mathrm{N}_{2}\right)$, and $30 \mathrm{~mL} \mathrm{~min}^{-1}$ and $300 \mathrm{~mL} \mathrm{~min}^{-1}$ for $\mathrm{H}_{2}$ and synthetic flame gas, respectively. The sample injection split mode was $1 / 80$. The fatty acids were identified by comparing the relative retention time of the FAME peaks of the samples with the fatty acid methyl ester standards (Sigma, St. Louis, Missouri, USA) by spiking the samples with the standard. The peak areas were determined by the Star software (Varian, Walnut Creek, California, USA). Data were expressed as percentages for normalized area of fatty acids (Visentainer, 2012).

\section{Statistical analysis}

The experimental design was completely randomized with three treatments and 10 replicates. All variables were previously submitted to normality test by Univariate proceeding (SAS/STAT, Version 9.1.2, SAS Institute, 
Cary, North Carolina, USA). The variables which the normal distribution were accepted by the Shapiro - Wilk test at $5 \%$ probability were interpreted by ANOVA (SAS Institute) and differences were tested by Tukey test $(\mathrm{P}<$ $0.05)$, being the variables measured following the model: $\mathrm{Y}_{\mathrm{ij}}=\mu+\mathrm{d}_{\mathrm{i}}+\mathrm{e}_{\mathrm{ij}}$, where $Y_{i j}$ is observation on animal $j$ fed with diet $i ; \mu$ is mean treatments; $d_{i}$ is effect of diet $i$; 1,2 , and 3 ; and $e_{i j}$ is residual error. The variables which did not present discrete data (marbling and texture) were analyzed by the Kruskal-Wallis test $(\mathrm{P}<0.05)$.

\section{RESULTS AND DISCUSSION}

\section{Meat quality}

The addition of propolis and essential oils in the diet had no effect on the $\mathrm{pH}$ measured $24 \mathrm{~h}\left(\mathrm{pH}_{24 \mathrm{~h}}\right)$ after slaughter (Table 3). However, the mean value for $\mathrm{pH}$ (5.9) is slightly above the normal $\mathrm{pH}$ of meat, which is from 5.5 to 5.8 (Mounier et al., 2006). This could be affected by a factor not evaluated in our study (stress) before slaughter, likely influenced because they were crossed with Zebu and British breeds (1/2 Aberdeen Angus vs. 1/2 Nellore). Animals with Bos indicus genes are more easily stressed during transportation and handling of animals at abattoirs than Bos taurus, thus explaining the cause of this change in meat $\mathrm{pH}_{24 \mathrm{~h}}$ (Voisinet et al., 1997). Meat with $\mathrm{pH}_{24 \mathrm{~h}}$ above 5.8 has the potential quality problem of dark red color meat and could cause industry economic losses. The main problems of meat $\mathrm{pH}_{24}$ above 6.0 are increased tenderness variation, increased water holding capacity, poor palatability, microorganisms growing to unacceptable levels and developing off-odors, and often

Table 3. Meat quality of crossbred bulls finished in feedlot.

\begin{tabular}{|c|c|c|c|c|c|}
\hline \multirow[b]{2}{*}{ Item } & \multicolumn{3}{|c|}{ Diets } & \multirow[b]{2}{*}{ SEM } & \multirow[b]{2}{*}{$\mathrm{P}<\mathrm{F}$} \\
\hline & $\mathrm{CON}$ & PRO & OIL & & \\
\hline $\mathrm{pH}$ & 5.92 & 5.91 & 5.90 & 0.35 & 0.60 \\
\hline Fat thickness, mm & 4.35 & 5.81 & 4.78 & 0.30 & 0.12 \\
\hline Longissimus muscle, $\mathrm{cm}^{2}$ & 58.3 & 57.2 & 58.4 & 1.27 & 0.93 \\
\hline \multicolumn{6}{|l|}{ Marbling $^{1}$} \\
\hline - Traces, \% & 60 & 20 & 30 & -- & -- \\
\hline - Light, $\%$ & 30 & 60 & 40 & -- & -- \\
\hline - Small, \% & 0 & 10 & 20 & -- & -- \\
\hline - Mean, \% & 10 & 10 & 10 & -- & -- \\
\hline \multicolumn{6}{|l|}{ Texture $^{2}$} \\
\hline - Fine, $\%$ & 30 & 40 & 60 & -- & -- \\
\hline - Very fine, $\%$ & 70 & 60 & 40 & -- & -- \\
\hline $\mathrm{L}^{*}$ & 37.1 & 35.0 & 37.6 & 0.58 & 0.18 \\
\hline$a^{*}$ & 17.0 & 17.0 & 18.0 & 0.43 & 0.53 \\
\hline$b^{*}$ & 5.60 & 5.51 & 6.52 & 0.33 & 0.45 \\
\hline $\mathrm{C}^{*}$ & 17.9 & 17.8 & 19.2 & 0.51 & 0.49 \\
\hline $\mathrm{H}^{*}$ & 31.1 & 32.0 & 32.1 & 0.13 & 0.49 \\
\hline $\begin{array}{l}\text { Thiobarbituric acid reactive } \\
\text { substances }^{3}\end{array}$ & 0.09 & 0.08 & 0.07 & 0.01 & 0.40 \\
\hline WBSF, $\mathrm{kg}$ & 3.34 & 3.34 & 3.22 & 0.30 & 0.20 \\
\hline
\end{tabular}

CON: Control diet, PRO: diet with propolis inclusion, OIL: diet with essential oils inclusion, SEM: standard error of the mean, $\mathrm{L}^{*}$ : lightness of color, $\mathrm{a}^{*}$ : red/ green value, $\mathrm{b}^{*}$ : yellow/blue value, $\mathrm{C}^{*}$ : chroma index, $\mathrm{H}^{*}$ : hue angle index, WBSF: Warner-Bratzler shear force.

${ }^{1}$ Scale (18 to 16 : abundant, 15 to 13 : moderate, 12 to 10 : mean, 9 to 7 : small, 6 to 4 : light, and 3 to 1 : traces).

${ }^{2}$ Scale (very fine: 5 , fine: 4 , slightly: 3 , coarse: 2 , and very coarse: 1 ).

${ }^{3} \mathrm{mg}$ malonaldehyde $\mathrm{kg}^{-1}$ meat. slime formation (Campo et al., 2006). Meat with $\mathrm{pH}_{24}$ greater than 5.8 is thought to be the result of pre-slaughter glycogen depletion, and the consequent inability of muscle to accumulate adequate lactic acid concentration. Glycogen depletion depends on physical exhaustion and psychological pre-slaughter stress of cattle.

Mean fat thickness and LM area were unaffected by the addition of natural additives $24 \mathrm{~h}$ after slaughter (Table 3). The values observed for the fat thickness (5.0 $\mathrm{mm})$ and LM area $\left(58 \mathrm{~cm}^{2}\right)$ were consistent with results observed in Brazilian cattle finished in a feedlot (Rotta et al., 2009). Thus, the inclusion of propolis and essential oils in the diets of crossbred bulls finished in a feedlot and $\mathrm{pH}_{24 \mathrm{~h}}$ slightly above the normal of meat, had no effect on the fat thickness an meat subjective characteristics, as was observed in previous studies with cattle Nellore (Zawadzki et al., 2011b).

In the three treatments evaluated, was possible identify four types of marbling score: traces, light, small, and mean; $60 \%$ of animals from treatment CON presented traces, $30 \%$ light, and $10 \%$ mean. In relation of the treatment PRO, $20 \%$ of animals presented traces, $60 \%$ light, $10 \%$ small, and $10 \%$ mean. For animals from treatment OIL, $30 \%$ presented traces, $40 \%$ light, $20 \%$ small, and $10 \%$ mean. Thus, the utilization of natural additives increased $7.3 \%$ of marbling, indicating higher average for score light.

The texture of LM should be fine or very fine; $30 \%$ of bulls from treatment CON presented score fine and $70 \%$ very fine. On the other hand, $40 \%$ of bulls from treatment PRO presented score fine and $60 \%$ very fine. However, $60 \%$ bulls from treatment OIL presented texture fine and $40 \%$ very fine.

Likewise color parameters lightness $\left(\mathrm{L}^{*}\right)$, redness $\left(\mathrm{a}^{*}\right)$, and yellowness $\left(\mathrm{b}^{*}\right)$ were not different among CON, PRO, and OIL diets (Table 3). Additionally, in previous publications (Arnold et al., 1993) the supranutritional supplementation of grain-fed cattle did not affect meat stability when compared to non-supplemented cattle. This characteristic could be partially attributed to levels of $\alpha$-tocopherol present at the beginning of the experiment and the protective action of other antioxidants in muscles from non-supplemented grain-fed animals. Others studies (Realini et al., 2004) indicated little or no benefit from vitamin antioxidant supplementation on the color stability of fresh beef from cattle fed good quality pasture immediately before grain feeding. The depletion of $\alpha$-tocopherol in muscle is slow (Arnold et al., 1993) when cattle have access to good quality grass prior to grain feeding, as was the case in the current study. Meat from non-supplemented cattle will have a high content of $\alpha$-tocopherol and other antioxidants from the pasture (Aerts et al., 1999).

Chroma $\left(\mathrm{C}^{*}\right)$ and hue angle $\left(\mathrm{H}^{*}\right)$ values of $\mathrm{LM}$ are shown in Table 3. Propolis and essential oil supplementation did not alter $\mathrm{C}^{*}$ or $\mathrm{H}^{*}$ of $\mathrm{LM}$ values. Propolis and essential 
oil supplementation maintained the saturation over the limiting value of 18 , which is considered acceptable in beef (Liu et al., 1995). Both $\mathrm{C}^{*}$ and $\mathrm{H}^{*}$ values reported in this study (18 and 31) are similar to those reported in strip-loin and cube-roll steaks (Rodas-González et al., 2011).

\section{Thiobarbituric acid reactive substances (TBARS)}

Thiobarbituric acid reactive substances values were not different among CON, PRO, and OIL diets (Table 3). One of the most important causes of meat deterioration is lipid oxidation, which is affected by intramuscular fatty acid composition, particularly polyunsaturated fatty acids (Faustman et al., 2010). Lipid oxidation may lead to drip losses, off-odor and off-flavor development, the production of potentially toxic compounds and induce the oxidation of myoglobin (Faustman et al., 2010). The oxidation levels observed in the present study are consistent with animals fed forage and finished with concentrates 55 d before slaughter (Realini et al., 2004). Thus, propolis and essential oils in the bulls' diets did not affect the lipid oxidation of the meat. Meat from steers at $0 \mathrm{~h}$ had low TBARS values (0.08 $\mathrm{mg} \mathrm{MDA} \mathrm{kg}^{-1}$ meat), which was a logical observation once the meat had been chilled after slaughter. However, MDA levels were below the acceptance limit, which is at $0.2 \mathrm{mg} \mathrm{MDA} \mathrm{kg}^{-1}$ fresh tissue (Campo et al., 2006). The diets in the current study consisted of corn silage and cereal, which would possess good vitamin E contents and make the samples oxidatively stable (Campo et al., 2006).

\section{Warner-Bratzler Shear Force (WBSF)}

The Warner-Bratzler shear force value in LM was similar among diets (Table 3). Although the meat $\mathrm{pH}_{24 \mathrm{~h}}$ was high, which characterizes low quality meat, the WBSF observed $(3.3 \mathrm{~kg})$ in this experiment classifies the meat as extremely tender (Wheeler et al., 1997). The crossbred B.taurus vs. $B$. indicus cattle is known for producing meat with less tenderness than animals with B. taurus genes (O'Connor et al., 1997). However, a study performed under similar conditions with similar genetic groups of cattle showed a WBSF from 2.0 to $3.3 \mathrm{~kg}$ (Maggioni et al., 2012). The low WBSF could be partially attributed to the high $\mathrm{pH}$ (5.9) observed in the meat, which classifies as type DFD (dark, firm, and dry). This DFD meat is typically softer, since it has higher myofibrillar fragmentation, which occurs when cooked, and there are lower cooking losses (Viljoen et al., 2002). Also, the smaller diameter of the muscle fibers of cattle with Zebu genes could have contributed to the results (Maggioni et al., 2012). Studies have shown that muscle fibers with smaller diameters also decreased shear force (Lepetit, 2008) and intramuscular fat content could have associated with tenderness (Purchas et al., 2002). Nevertheless, the obtained WBSF results $(<4.0 \mathrm{~kg})$ ensure a tenderness that should result in high consumer acceptance (Shackelford et al., 1994).

\section{Chemical composition}

Mean moisture, ash, protein, and total lipid measurements of LM were unaffected among the CON, PRO, and OIL diets (Table 4). The moisture percentage from bulls in all diets had low variations (from $73.1 \%$ to $74.0 \%$ ). Moisture percentage variations for meat from intensively reared cattle occurs when there is a variation in lipid percentage (Rotta et al., 2009). The ash percentage is rarely influenced by the nutrition system (Padre et al., 2007). Protein percentage for meat from bulls ranged from $23.6 \%$ to $24.1 \%$. That protein percentage in LM varied between $21 \%$ and $24 \%$ with nutritional status, according toAricetti et al. (2008) and Rotta et al. (2009). In this study, lipid percentages varied from $1.4 \%$ to $1.8 \%$. The total lipids in LM of beef cattle finished in a feedlot system can vary from 2\% to 4\% (Padre et al., 2007; Prado et al., 2009). This percentage is the parameter that is most influenced by nutrition. Thus, the lipid percentages in meat were low since bulls were crossbred between $B$. taurus and $B$. indicus. Bos indicus cattle tend to have low lipid contents in the LM (Prado et al., 2008; 2009). Therefore, propolis and essential oil additions to the diets of crossbred bulls finished in a feedlot and fed a high-energy diet did not affect the chemical composition of meat, as observed by other authors using similar conditions (Valero et al., 2011; Zawadzki et al., 2011a).

Table 4. Chemical composition of Longissimus muscle of crossbred bulls finished in feedlot.

\begin{tabular}{|c|c|c|c|c|c|}
\hline \multirow[b]{2}{*}{ Item } & \multicolumn{3}{|c|}{ Diets } & \multirow[b]{2}{*}{ SEM } & \multirow[b]{2}{*}{$\mathrm{P}<\mathrm{F}$} \\
\hline & $\mathrm{CON}$ & PRO & $\overline{\text { OIL }}$ & & \\
\hline & & $\%$ & & & \\
\hline Moisture & 74.0 & 73.0 & 74.0 & 0.21 & 0.10 \\
\hline Ash & 1.09 & 1.10 & 1.09 & 0.01 & 0.87 \\
\hline Protein & 24.1 & 23.7 & 23.6 & 0.24 & 0.69 \\
\hline Total lipids & 1.78 & 1.79 & 1.43 & 0.12 & 0.38 \\
\hline
\end{tabular}

CON: Control diet, PRO: diet with propolis inclusion, OIL: diet with essential oils inclusion, SEM: standard error of the mean

\section{Fatty acid composition}

The addition of propolis and essential oils in the diet had no effect on fatty acid composition of LM (Table 5). Previous studies with Nellore bulls (Zawadzki et al., 2011a) showed a minimal effect on LM fatty acid composition when propolis was included in the diet of crossbred cattle finished in similar condition to this experiment. Similarly, Valero et al. (2011) observed an effect of propolis only for two fatty acids of the 20 analyzed (an increase in 18:2 cis 9, trans 11, and decrease in 22:6n-3-docosahexaenoic acid) for the LM of crossbred bulls finished in a feedlot.

The additives (propolis or essential oils) did no influence saturated (SFA), monounsaturated (MUFA), and polyunsaturated (PUFA) fatty acid percentages on LM of bulls finished in a feedlot. The majority of the fatty acids observed on LM were MUFA (47.9\%) followed by SFA $(46.0 \%)$ and PUFA (6.0\%). Similarly, other study (Valero et al., 2011) did not observe changes in total fatty acid for LM from crossbred bulls finished in a feedlot. 
Table 5. Fatty acid composition of Longissimus muscle of crossbred bulls finished in feedlot.

\begin{tabular}{|c|c|c|c|c|c|}
\hline \multirow[b]{2}{*}{ Fatty acid } & \multicolumn{3}{|c|}{ Diets } & \multirow[b]{2}{*}{ SEM } & \multirow[b]{2}{*}{$\mathrm{P}<\mathrm{F}$} \\
\hline & $\mathrm{CON}$ & PRO & OIL & & \\
\hline \multicolumn{6}{|c|}{$\%$ fatty acid identified } \\
\hline $12: 0$ & 0.03 & 0.02 & 0.02 & 0.01 & 0.42 \\
\hline 14:0 & 2.49 & 2.52 & 2.57 & 0.08 & 0.63 \\
\hline $14: 1 n-7$ & 0.53 & 0.61 & 0.54 & 0.03 & 0.31 \\
\hline $15: 0$ & 0.44 & 0.48 & 0.47 & 0.01 & 0.56 \\
\hline $15: 1 n-9$ & 0.15 & 0.14 & 0.14 & 0.01 & 0.74 \\
\hline $16: 0$ & 25.00 & 24.90 & 25.50 & 0.28 & 0.47 \\
\hline $16: 1 n-9$ & 3.02 & 3.27 & 3.08 & 0.10 & 0.13 \\
\hline $16: 1 n-7$ & 0.39 & 0.39 & 0.39 & 0.01 & 0.62 \\
\hline $17: 0$ & 1.42 & 1.49 & 1.49 & 0.05 & 0.98 \\
\hline $17: 1 n-9$ & 1.07 & 1.24 & 1.14 & 0.04 & 0.27 \\
\hline 18:0 & 16.30 & 15.10 & 16.00 & 0.33 & 0.09 \\
\hline $18: 1 n-7$ & 1.02 & 1.16 & 1.13 & 0.09 & 0.57 \\
\hline $18: 1 n-9$ cis & 40.70 & 41.00 & 39.80 & 0.51 & 0.92 \\
\hline $18: 1 n-11$ trans & 1.03 & 0.96 & 0.96 & 0.04 & 0.80 \\
\hline $18: 2 n-6 \mathrm{c}$ & 3.58 & 3.78 & 3.78 & 0.18 & 0.69 \\
\hline $18: 2$ cis 9 , trans 11 & 0.27 & 0.27 & 0.27 & 0.01 & 0.85 \\
\hline $18: 3 n-3$ & 0.41 & 0.44 & 0.46 & 0.02 & 0.82 \\
\hline $18: 3 n-6$ & 0.12 & 0.13 & 0.13 & 0.01 & 0.37 \\
\hline $20: 0$ & 0.08 & 0.09 & 0.08 & 0.01 & 0.83 \\
\hline $20: 1 n-9$ & 0.01 & 0.01 & 0.01 & 0.01 & 0.18 \\
\hline $20: 2 n-6$ & 0.01 & 0.01 & 0.01 & 0.01 & 0.59 \\
\hline $20: 3 n-3$ & 0.04 & 0.05 & 0.05 & 0.01 & 0.79 \\
\hline $20: 4 n-6$ & 1.18 & 1.21 & 1.19 & 0.09 & 0.82 \\
\hline $20: 5 n-3$ (EPA) & 0.05 & 0.05 & 0.04 & 0.01 & 0.53 \\
\hline $22: 0$ & 0.17 & 0.20 & 0.19 & 0.01 & 0.58 \\
\hline $22: 4 n-6$ & 0.18 & 0.21 & 0.17 & 0.01 & 0.29 \\
\hline $22: 5 n-3$ (DPA) & 0.15 & 0.17 & 0.16 & 0.01 & 0.33 \\
\hline $22: 6 n-3$ (DHA) & 0.18 & 0.21 & 0.19 & 0.08 & 0.27 \\
\hline
\end{tabular}

CON: Control diet, PRO: diet with propolis inclusion, OIL: diet with essential oils inclusion, SEM: standard error of the mean, EPA: eicosapentaenoic acid, DPA: docosapentaenoic acid, DHA: docosahexaenoic acid.

However, Zawadzki et al. (2011a) observed that the inclusion of propolis in the diets decreased MUFA for LM of bulls finished in a feedlot. Similarly, Prado et al. (2008) observed similar percentages of SFA, MUFA, and PUFA in bulls finished on similar handling conditions as the ones in this experiment. Thus, SFA, MUFA, and PUFA fatty acid percentages vary minimally in function this diet.

Likewise, propolis and essential oils had no effect on the percentage of $n-3$ and $n-6$ fatty acids on LM (Table 6). Previous studies (Valero et al., 2011; Zawadzki et al., 2011a) showed no effect of propolis inclusion on $n$-3 or $n-6$ fatty acid percentages on LM of bulls finished in a feedlot. The percentage of $n-3$ fatty acids was low in comparison to $n-6$ primarily due to $\mathrm{C} 18: 2 n-6$, it appears on high concentrations when compared to $\mathrm{C} 18: 3 n-3$.

The PUFA/SFA ratio (0.13) was low for all diets (Table 6 ). Human diet should have PUFA/SFA values of 0.4 (HMSO, 1994). No difference was observed for $n-6 / n-3$ ratio among different diets. In this study, the average observed for $n-6 / n-3$ was 6.9 . This ratio should be lower than 4.0 (HMSO, 1994). Several gram-positive bacteria are involved in ruminal biohydrogenation of unsaturated dietary fatty acids. Therefore, feeding essential oils could lower the biohydrogenation of fatty acids by reducing the number and activity of bacteria involved in the biohydrogenation of unsaturated fatty acids. However, the
Table 6. Fatty acid sum and ratio of Longissimus muscle of crossbred bulls finished in feedlot.

\begin{tabular}{|c|c|c|c|c|c|}
\hline \multirow[b]{2}{*}{ Item } & \multicolumn{3}{|c|}{ Diets } & \multirow[b]{2}{*}{ SEM } & \multirow[b]{2}{*}{$\mathrm{P}<\mathrm{F}$} \\
\hline & $\mathrm{CON}$ & PRO & OIL & & \\
\hline & \multicolumn{3}{|c|}{$\%$ fatty acid identified } & & \\
\hline Saturated fatty acid (SFA) & 46.20 & 45.10 & 46.70 & 0.46 & 0.30 \\
\hline Monounsaturated fatty acid & 47.90 & 48.70 & 47.20 & 0.58 & 0.69 \\
\hline Polyunsaturated fatty acid (PUFA) & 5.84 & 6.16 & 6.12 & 0.28 & 0.53 \\
\hline$n-6$ & 4.89 & 5.14 & 5.10 & 0.19 & 0.64 \\
\hline$n-3$ & 0.68 & 0.75 & 0.75 & 0.09 & 0.34 \\
\hline PUFA/SFA & 0.13 & 0.14 & 0.13 & 0.01 & 0.40 \\
\hline$n-6 / n-3$ & 7.18 & 6.88 & 6.80 & 0.04 & 0.06 \\
\hline
\end{tabular}

CON: Control diet, PRO: diet with propolis inclusion, OIL: diet with essential oils inclusion, SEM: standard error of the mean

essential oils mix (200 to $400 \mathrm{mg} \mathrm{L}^{-1}$ ) in the diets increased the concentration of conjugated linoleic acid (CLA), a health-promoting fatty acid and in milk fat (Benchaar et al., 2007). However, data on the effects of essential oils and their compounds on fatty acid composition for the LM of beef cattle are required.

\section{CONCLUSIONS}

Addition of natural additives as propolis extract or essential oil from cashew and castor in the diet of bulls finished in a feedlot did not change quality of Longissimus dorsi muscle. Thus, these two additives that improve animal performance and feed efficiency as observed in other studies could be added in the diets for animal finished in feedlot system without to change meat quality.

\section{ACKNOWLEDGEMENTS}

The current project was supported by the Araucaria Foundation, a fund of the state of Paraná and the Brazilian Council for Research and Technological Development (CNPq). The authors would like to thank Processing Inc. (Biopar - Bioenergia do Paraná, Rolândia, Paraná, Brazil) for providing the glycerin and Oligo Basics Agroindustrial Ltda. (Cascavel, Paraná, Brazil), financial resources, castor oil and cashew nut shell liquid used in this research. Trade names or commercial products in this publication are mentioned solely for the purpose of providing specific information and do not imply recommendations by the Department of Animal Science, State University of Maringá, Maringá, Paraná, Brazil.

\section{LITERATURE CITED}

Aerts, R.J., T.N. Barry, and W.C. McNabb. 1999. Polyphenols and agriculture: beneficial effects of proanthocyanidins in forages. Agriculture, Ecosystems \& Environment 75:1-12

AOAC. 1998. Official methods of analysis. Association of Official Analytical Chemists (AOAC), Arlington, Virginia, USA.

Aricetti, J.A., P.P. Rotta, R.M. Prado, D. Perotto, J.L. Moletta, M. Matsushita, et al. 2008. Carcass characteristics, chemical composition and fatty acid profile of Longissimus muscle of bulls and steers finished in a pasture system. Asian-Australasian Journal of Animal Science 21:1441-1448. 
Arnold, R.N., K.K. Scheller, S.C. Arp, S.N. Williams, and D.M. Schaefer. 1993. Dietary $\alpha$-tocopheryl acetate enhances beef quality in Holstein and beef breed steers. Journal of Food Science 58:28-33.

Benchaar, C., S. Calsamiglia, A.V. Chaves, G.R. Fraser, D. Colombatto, T.A. McAllister, et al. 2008. A review of plantderived essential oils in ruminant nutrition and production. Animal Feed Science and Technology 145:209-228.

Benchaar, C., H.V. Petit, R. Berthiaume, D.R. Ouellet, J. Chiquette, and P.Y. Chouinardt. 2007. Effects of essential oils on digestion, ruminal fermentation, rumen microbial populations, milk production, and milk composition in dairy cows fed alfalfa silage or corn silage. Journal of Dairy Science 90:886-897.

Bligh, E.G., and W.J. Dyer. 1959. A rapid method of total lipid extraction and purification. Canadian Journal of Biochemistry and Physiology 37:911-917.

Campo, M.M., G.R. Nute, S.I. Hughes, M. Enser, J.D. Wood, and R.I. Richardson. 2006. Flavour perception of oxidation in beef. Meat Science 72:303-311.

Faustman, C., Q. Sun, R. Mancini, and S.P. Suman. 2010. Myoglobin and lipid oxidation interactions: Mechanistic bases and control. Meat Science 86:86-94.

Greathead, H. 2003. Plants and plant extracts for improving animal productivity. Proceedings of the Nutrition Society 62:279-290.

Havsteen, B.H. 2002. The biochemistry and medical significance of the flavonoids. Pharmacology \& Therapeutics 96:67-202.

HMSO. 1994. Aspects of cardiovascular disease. Report of the Cardiovascular Review Group of the Committee of Medical Aspects of Food Policy nr 46. p. 37-46. Department of Health, Her Majesty's Stationery Office (HMSO), Norwich, Norfolk, UK.

Ito, R.H., T. Ducatti, J.M. Prado, I.M. Prado, P.P. Rotta, M.V. Valero, et al. 2010. Soybean oil and linseed grains on performance and carcass characteristics of crossbred bulls finished in feedlot. Semina: Ciências Agrárias 31:259-268.

Lepetit, J. 2008. Collagen contribution to meat toughness: Theoretical aspects. Meat Science 80:960-967.

Liu, Q., M. Lanari, and D. Schaefer. 1995. A review of dietary vitamin $\mathrm{E}$ supplementation for improvement of beef quality. Journal of Animal Science 73:3131-3140.

Maggioni, D., I.N. Prado, F. Zawadzki, M.V. Valero, J.A. Marques, A.M. Bridi, et al. 2012. Grupos genéticos e graus de acabamento sobre qualidade da carne de bovinos. Semina: Ciências Agrárias 33:391-402

Mounier, L., H. Dubroeucq, S. Andanson, and I. Veissier. 2006. Variations in meat $\mathrm{pH}$ of beef bulls in relation to conditions of transfer to slaughter and previous history of the animals. Journal of Animal Science 84:1567-1576.

NRC. 2000. Nutrient requirements of beef cattle. 7th ed. National Academies Press, Washington, D.C., USA

O'Connor, S.F., J.D. Tatum, D.M. Wulf, R.D. Green, and G.C. Smith. 1997. Genetic effects on beef tenderness in Bos indicus composite and Bos taurus cattle. Journal of Animal Science 75:1822-1830.

Padre, R.G., J.A. Aricetti, S.T.M. Gomes, R.H.T.B. Goes, F.B. Moreira, I.N. Prado, et al. 2007. Analysis of fatty acids in Longissimus muscle of steers of different genetic breeds finished in pasture systems. Livestock Science 110:57-63.

Patra, A.K. 2011. Effects of essential oils on rumen fermentation, microbial ecology and ruminant production. Asian Journal of Animal Veterinary Advances 6:416-428.

Prado, J.M., I.N. Prado, J.V. Visentainer, P.P. Rotta, D. Perotto, J.L. Moletta, et al. 2009. The effect of breed on the chemical composition and fatty acid profile of the Longissimus dorsi muscle of Brazilian beef cattle. Journal of Animal and Feed Sciences 18:231-240.

Prado, I.N., P.P. Rotta, R.M. Prado, J.V. Visantainer, J.L. Moletta, and D. Perotto. 2008. Carcass characteristics and chemical composition of the Longissimus muscle of Purunã and 1/2 Purunã vs. 1/2 Canchin bulls meat quality of bulls. Asian-Australasian Journal of Animal Sciences 21:1296-1302.
Prado, O.P.P., L.M. Zeoula, L.P.P. Moura, S.L. Franco, S.B. Paiva, and P.B. Arcuri. 2010a. Isolation and expeditious morphological, biochemical and kinetic characterization of propolis-tolerant ruminal bacteria. Revista Brasileira de Zootecnia 39:2048-2054.

Prado, O.P.P., L.M. Zeoula, L.P.P. Moura, S.L. Franco, I.N. Prado, e G. Jacobi. 2010b. Efeito da adição de própolis e monensina sódica na digestibilidade e características ruminais em bubalinos alimentados com dieta à base de forragem. Revista Brasileira de Zootecnia 39:2055-2065.

Purchas, R.W., D.L. Burnham, and S.T. Morris. 2002. Effects of growth potential and growth path on tenderness of beef Longissimus muscle from bulls and steers. Journal of Animal Science 80:3211-3221

Realini, C.E., S.K. Duckett, G.W. Brito, M. Dalla Rizza, and D. Mattos. 2004. Effect of pasture vs. concentrate feeding with or without antioxidants on carcass characteristics, fatty acid composition, and quality of Uruguayan beef. Meat Science 66:567-577.

Righi, A.A., T.R. Alves, G. Negri, L.M. Marques, H. Breyer, and A. Salatino. 2011. Brazilian red propolis: unreported substances, antioxidant and antimicrobial activities. Journal of Science and Food Agriculture 91:2363-2370.

Rodas-González, A., C. Narváez-Bravo, M.M. Brashears, H.B. Rogers, J.L. Tedford, G.O. Clark, et al. 2011. Evaluation of the storage life of vacuum packaged Australian beef. Meat Science $88: 128-138$.

Rotta, P.P., R.M. Prado, I.N. Prado, M.V. Valero, J.V. Visentainer, and R.R. Silva. 2009. The effects of genetic groups, nutrition, finishing systems and gender of Brazilian cattle on carcass characteristics and beef composition and appearance: a review. Asian-Australasian Journal of Animal Sciences 22:1718-1734.

Russell, J.B., and A.J. Houlihan. 2003. Ionophore resistance of ruminal bacteria and its potential impact on human health. FEMS Microbiology Reviews 27:65-74.

Schäberle, T.F., and I.M. Hack. 2014. Overcoming the current deadlock in antibiotic research. Trends in Microbiology 22:165167.

Shackelford, S.D., M. Koohmaraie, and J.W. Savell. 1994. Evaluation of Longissimus dorsi muscle $\mathrm{pH}$ at three hours Post mortem as a predictor of beef tenderness. Meat Science 37:195-204.

Valero, M.V., F. Zawadzki, M.C. Françozo, M.S. Farias, P.P. Rotta, I.N. Prado, et al. 2011. Sodium monensin or propolis extract in the diet of crossbred ( $1 / 2$ Red Angus vs. $1 / 2$ Nellore) bulls finished in feedlot: chemical composition and fatty acid profile of the Longissimus muscle. Semina: Ciências Agrárias 32:1617-1626.

Viljoen, H.F., H.L. Kock, and E.C. Webb. 2002. Consumer acceptability of dark, firm and dry (DFD) and normal $\mathrm{pH}$ beef steaks. Meat Science 61:181-185.

Visentainer, J.V. 2012. Aspectos analíticos da resposta do detector de ionização em chama para ésteres de ácidos graxos em biodiesel e alimentos. Química Nova 35:274-279.

Voisinet, B.D., T. Grandin, S.F. O'Connor, J.D. Tatum, and M.J. Deesing. 1997. Bos indicus-cross feedlot cattle with excitable temperaments have tougher meat and a higher incidence of borderline dark cutters. Meat Science 46:367-377.

Wheeler, T.L., S.D. Shackelford, L.P. Johnson, M.F. Miller, R.K. Miller, and M. Koohmaraie. 1997. A comparison of WarnerBratzler shear force assessment within and among institutions. Journal of Animal Science 75:2423-2432

Zawadzki, F., I.N. Prado, J.A. Marques, L.M. Zeoula, R.M. Prado, C.A. Fugita, et al. 2011a. Sodium monensin or propolis extract in the diet of Nellore bulls finished in feedlot: chemical composition and fatty acid profile of Longissimus muscle. Semina: Ciências Agrárias 32:1627-1636

Zawadzki, F., I.N. Prado, J.A. Marques, L.M. Zeoula, P.P. Rotta, B.B. Sestari, et al. 2011b. Sodium monensin or propolis extract in the diets of feedlot-finished bulls: effects on animal performance and carcass characteristics. Journal of Animal and Feed Sciences 20:16-25. 